\title{
RATE REGULATION AND THE INDUSTRIAL ORGANIZATION OF AUTOMOBILE INSURANCE
}

\author{
Susan J. Suponcic \\ Sharon Tennyson
}

Working Paper 5275

\section{NATIONAL BUREAU OF ECONOMIC RESEARCH 1050 Massachusetts Avenue \\ Cambridge, MA 02138 \\ September 1995}

The authors thank Kip Viscusi and other conference participants for useful comments on the paper. Financial support from the University of Pennsylvania Research Foundation is gratefully acknowledged. This paper was presented at the NBER conference on Property Casualty Insurance, organized by David Bradford, held February 10-11, 1995, in Cambridge, MA. Any opinions expressed are those of the authors and not those of the National Bureau of Economic Research.

(C) 1995 by S.J. Suponcic and Sharon Tennyson. All rights reserved. Short sections of text, not to exceed two paragraphs, may be quoted without explicit permission provided that full credit, including $\odot$ notice, is given to the source. 


\title{
RATE REGULATION AND THE INDUSTRIAL ORGANIZATION OF \\ AUTOMOBILE INSURANCE
}

\begin{abstract}
This paper analyzes the impact of rate regulation on the structure of insurance markets for private passenger automobile insurance. The paper argues that states' restrictions on automobile insurers' rates of return will distort the structure of the market by distorting insurers' entry and output decisions. Cross-sectional analysis of the numbers of firms and the relative market shares of firms of different organizational characteristics supports this argument, especially for those states which impose the most stringent regulation. The analysis suggests that increased regulatory stringency lowers the total number of firms selling in the market, and lowers the number of low cost and national firms in the market. The market shares of these latter two groups of firms are also significantly lowered by increased regulatory stringency. These findings hold even after controlling for other factors which may influence the relative prevalence of these firms in the market, and are robust to the assumption that regulatory stringency in a state is itself partially determined by the number and market shares of large, low cost producers.

Sharon Tennyson

Department of Insurance and Risk Management 302 CPC/3641 Locust Walk

University of Pennsylvania

Philadelphia, PA 19104

Susan J. Suponcic

Department of Public Policy and Management 3100 SH-DH/3620 Locust Walk University of Pennsylvania Philadelphia, PA 19104
\end{abstract}


Suponcic and Tennyson

\section{Introduction}

Property-liability insurance markets, especially those for personal coverages such as automobile insurance, have traditionally been closely regulated. Areas of government oversight include the imposition of licensing and capital requirements, the monitoring of solvency and liquidation of insolvent firms, and in some cases, direct regulation of insurance rates. Under the provisions of the McCarran Ferguson Act of 1945, this regulation is undertaken by the individual state governments rather than at the federal level. As a result, the extent of regulatory intervention and enforcement differs by geographic location.

A primary area of state differences in regulation is the degree to which rates for private passenger automobile insurance are regulated. Currently twenty six states intervene directly in the ratemaking process for automobile insurance. The most common method of rate regulation is the prior approval system, under which each insurer's rates must be approved by the state insurance commissioner prior to their introduction into the market. A few states instead require all insurers to charge rates which are set by the insurance commissioner, or by an industry rating bureau. The remaining states allow rates to be competitively determined, although most require that insurers file rate changes with the state commissioner.

The effects of rate regulation on insurers' underwriting margins have been the subject of numerous analyses.' Most studies assess underwriting results by the unit price of insurance, the ratio of premium revenue received to losses incurred by the insurer. This ratio is a measure of the average price paid by insureds per dollar of benefits (loss payments) received. Early studies tended to find that regulation raised unit prices for automobile insurance, suggesting that regulation promoted collusive pricing or inhibited price competition (Joskow, 1973; Ippolito, 
1979; Frech and Samprone, 1980). It must be borne in mind, however, that these studies examined the time period from the late 1960s to early 1970s, a period when virtually all states regulated ratesetting and deregulation was a very recent phenomenon. Later studies, availed of greater variability in regulatory regimes and longer time horizons for comparison, have consistently found the opposite result: lower unit prices for automobile insurance in states which regulate rates (Pauly, Kunreuther and Kleindorfer, 1986; Harrington, 1987; Grabowski, Viscusi and Evans, 1989). Thus, at least since the mid-1970s, rate regulation has had the effect of reducing insurers' premium revenues relative to insured losses, thereby lowering the average per unit price of insurance.

The magnitude of unit price reductions under regulation has been shown to be small on average, decreasing unit prices by .03 to .07 . The price-decreasing effects of regulation are significantly larger in a few selected states, however (Harrington, 1987; Grabowski, Viscusi and Evans, 1989). This latter finding has produced concerns about other distortionary effects of regulation. Researchers have investigated several potential unintended effects of stringent rate regulation. $^{2}$ Pauly, Kleindorfer and Kunreuther (1986) present evidence, based on the estimation of cost functions, that reducing prices via regulation lowers quality or service provision by insurers. Grabowski, Viscusi and Evans (1989) demonstrate that stringent rate regulation reduces insurance availability, where availability is assessed by the fraction of drivers insured through the residual market. Residual market pools exist in all states to provide insurance to drivers unable to obtain coverage in the open market. Regulation which holds prices below the competitive level will increase the fraction of drivers insured in the residual market, due to rationing in the voluntary market sector. The findings of Grabowski, Viscusi and 
Evans are consistent with this view of regulation for several highly regulated states. Kramer (1992) investigates the effects of rate regulation on insurance company financial health, and finds evidence of a relationship between stringent regulation of rates and an increased risk of insurer insolvency.

This paper investigates the extent to which rate regulation distorts the industrial structure of state automobile insurance markets. As pointed out by Harrington (1992), insurers may be reluctant to commit resources to regulated states, whether for market entry or expansion, if current regulation is excessively stringent or if the regulator cannot commit to an established level of regulation for future periods. Hence, the suppression of rates below open market levels will affect the strategic decisions of insurers operating in the state and of those considering entering. This will have implications for the number of sellers in the market and the relative market presence of different types of sellers.

Regulatory distortions to market structure seem especially likely in state-regulated insurance markets, due to differences in regulation across states. Since insurers are usually licensed to sell in more than one state, and much of an insurer's productive resources consist of relatively mobile financial assets, regulation which attempts to hold insurers' rates of return below that available in other states will be likely to affect decisions regarding insurer operations across states. All firms will of course attempt to avoid the adverse effects of restrictive regulation; however, their strategies for doing so and their ability to do so will depend upon their market position and their opportunity costs of regulatory avoidance. Our analysis focuses on how differences across insurers in costs, size, production technology and market position will lead to differences in responses to regulation, thereby distorting the industrial structure of the 
market.

The remainder of the paper is organized as follows. The next section outlines the industrial organization of automobile insurance markets, with particular emphasis on organizational and strategic differences across insurers. Section 3 discusses how these differences might lead to differences in responses to regulation. Section 4 compares insurance market structure across regulated and unregulated states. Sections 5 and 6 examine the effects of regulation in more detail, presenting multiple regression analysis of regulatory effects on the number of firms in the market and firms' market shares, respectively. The final section summarizes our findings and suggests future research avenues.

\section{The Industrial Organization of Automobile Insurance}

The private passenger automobile insurance market is generally thought to be structurally competitive, since there are a large number of sellers and entry and exit are relatively vigorous. Industry statistics for 1989, presented in Table 1, tend to support this view. We use 1989 as the basis for our cross-sectional analysis because it is a year of calm in the insurance business cycle, and it is the most recent year before major changes began in the insurance regulatory environment: 1989. was the last year that the major insurance rating bureaus issued advisory rates to their members, and the passage of California's Proposition 103 in late 1988 prompted consideration of regulatory initiatives in other states in subsequent years. These changes could differentially affect the competitive strategies or capabilities of different types of insurers, thereby affecting market structure.

A.M. Best Company repörts for 1989 identify 526 different groups and independent 
single companies which write positive auto insurance premiums in the United States. ${ }^{3}$ In keeping with the large number of sellers in the market, traditional measures of market concentration are relatively low in the industry: the four firm concentration ratio (C4) is 42 percent, and the Herfindahl-Hirschman Index (HHI) for the market is 659 , based on direct premiums written. These values are not large in comparison to other industries (Klein, 1989) and an HHI of under 1000 falls into the range defined as "unconcentrated" by U.S. Department of Justice merger guidelines.

A closer examination of the market reveals significant heterogeneity among sellers. First, insurance firms differ in terms of their formal organizational structure, including ownership form and distribution systems employed. The differences in distribution systems are especially important for this study. There are two major forms of distribution used in the industry. Some insurers, known generically as "direct writers", use sales agents who sell exclusively the products of that specific firm. Other firms utilize the more traditional independent agency system, under which agents contract to sell the policies of multiple insurance companies. Numerous empirical studies have shown direct writers to be lower cost sellers of automobile insurance than independent agency writers (Joskow, 1973; Cummins and Vanderhei, 1979; Barrese and Nelson, 1992). The precise source of the cost advantage to direct writing is not widely agreed upon, but it is apparent that direct writers' greater centralization and standardization of underwriting and claims handling functions contribute to this advantage. This implies, however, that direct writing entails greater investment in firm-specific assets by the insurer and greater sunk costs of entry into the market. Hence, the two distribution systems represent different production technologies. 
In accordance with their operating cost advantage, direct writers dominate the auto insurance market, achieving nearly a 65 percent market share in 1989 . However, due to the higher fixed costs of entering this segment of the market, there are fewer firms employing this system than the independent agency system. Of the 526 firms in the market only 101 are direct writers; the remaining 425 are independent agency writers. This fact, in conjunction with the statistics on market shares, implies that on average direct writers are much larger than independent agency writers. There are substantial size differences among direct writers, however; a few extremely large firms, such as State Farm and Allstate, significantly influence averages for the group. While the 10 largest direct writers in the industry each write well over $\$ 1$ billion in auto insurance premiums, the median-sized direct writer has premium revenue of only $\$ 39$ million. Nonetheless, this is significantly greater than the median premium volume of $\$ 10.5$ million for independent agency writers.

Variations in insurer size are considerable. The largest four writers in the market obtain market shares of 20 percent (State Farm), 12 percent (Allstate), 5 percent (Farmers) and 4 percent (Nationwide), respectively; only 13 other firms write over 1 percent of the market, yet the largest 50 firms write over 80 percent of all auto insurance premiums. Fully 90 percent of auto insurance premiums are written by only 90 firms. To put this into perspective, this means that 436 firms share only 10 percent of the private passenger auto insurance market. These extreme size differences are suggestive of substantial differences in cost structure across firms.

The existence of cost or technology differences is further suggested by the differences in market positioning across firms. ${ }^{4}$ Of the 526 firms writing in the market, 88 (16.3 percent of all firms) write over 90 percent of their insurance premiums in private passenger automobile 
lines, and 233 firms (44.3 percent of firms) write at least 50 percent of their business in auto insurance. Since private passenger auto insurance makes up only 35 percent of total propertyliability insurance premiums nationally, we classify these latter insurers as "auto specialists". This group contains several high profile auto insurers, including State Farm and Allstate, as well as a large number of relatively small specialist firms. At the other extreme from the auto specialists, however, 94 firms (17.9 percent of firms) write under 10 percent of their business in private passenger auto insurance. This latter category of firms includes a number of wellknown brand name insurance writers, including Chubb, Firemans' Fund and CIGNA. Although these firms may write substantial premium volume in private passenger auto insurance, their relative focus on these lines is likely to be limited.

Insurers also differ greatly in the extent of geographic areas served. For example, only 78 of the 526 firms in the market write auto insurance in all 9 census divisions in the country; the remainder sell in only some regions of the country, and 191 firms sell in only a single state. Hence a vast majority of firms in the market have operations which are concentrated in particular geographic areas. While the national firms (those which sell in all 9 census divisions) $)^{5}$ make up only 15 percent of insurance providers by number, these firms write 70 percent of total private passenger auto insurance premium volume. This implies that insurance markets are highly segmented by geographic location - with relatively few firms writing the bulk of premiums nationally and a much larger number of local or regional firms writing the balance of the market in their particular area.

This brief portrait of the national market highlights the great variation across firms in terms of size, geographic focus and relative specialization in automobile insurance. These 
differences are likely to reflect underlying differences in production and cost technologies. Moreover, a comparatively small number of firms, relative to the total number in the market, serves the vast majority of the market at the national level. This suggests that this relatively small number of large producers possess a cost or technological advantage over the remainder of the market.

In addition, the market segmentation by geographic location implies that auto insurance markets may differ substantially across states, and that state markets may look very different from what is implied by national market statistics. There is some evidence of both of these features in the data, summarized in the second column of Table 1. For example, the number of sellers in each state varies from 33 to 151 , with a mean value of 103 , much lower than the national total of 526 firms. State-level values for $\mathrm{C} 4$ vary from 33.2 percent to 80.4 percent, with a mean of 54 percent; the HHI by state ranges from 503 to 2220, with a mean of 1049 . Thus, market concentration varies a great deal across states, and is generally greater than at the national level.

The number and market shares of different types of sellers also varies across states. For example, the number of direct writers per state varies from 8 to 40 , with a mean value of 28 ; direct writer market share by state ranges from 28 percent to 88 percent, with a mean value of 64 percent. The number of national writers ranges from 30 to 73 across states, with a mean of 63, and their state market share varies from 41 percent to 99 percent, with a mean of 70 percent. The number of auto specialists per state ranges from 7 to 60 , with a mean of 34 , and their market share ranges from 33 percent to 82 percent, with a mean of 65 percent.

These differences in numbers of firms and relative market shares across states suggest 
that the effects of rate regulation on market structure may vary greatly across states. It is also possible that this diversity in fact reflects the effects of regulation, to the extent that it distorts firms' entry and output decisions. The remaining sections of the paper further develop and explore the hypothesis that differences in state insurance market structure are related to regulatory stringency.

\section{Insurer Responses to Stringent Regulation}

This section considers how insurers' choices regarding capacity allocation and output may respond to restrictive regulation of rates in a state insurance market. Consistent with the evidence presented in the previous section, we assume that the industry is characterized by a relatively small number of large firms which enjoy a persistent cost advantage over the remaining firms in the market. Firms engage in Bertrand competition over prices, but limited capacity implies that the large firms do not meet the entire market demand. Entry barriers, perhaps due to scarce managerial inputs or to increasing returns to scale, protect this segment of the industry from vigorous entry. These features of the market imply that the large firms earn greater rates of return than the fringe firms in unregulated markets.

In considering the effects of regulation, it is important to keep in mind that rate regulation does not impose a uniform price constraint on insurers. Under the prior approval system, each insurer's rate proposal is supported by data on its loss and expense experience; the proposed rates are then evaluated with respect to some measure of a fair rate of return for the insurer. Hence, rates can and do vary across insurers; regulation simply limits the profitability of business written. The implications of profit regulation will differ from those of a regulatory 
price ceiling. In particular, limits on rates of return will be binding for the large, low cost insurance providers and will therefore distort their decision making.

To understand the potential effects of regulation on insurance market structure, it is useful to distinguish between insurer decisions regarding market entry and exit, and decisions regarding output levels for a firm which does write insurance in the market. These two effects together will determine the effects of regulation on the equilibrium market structure.

We consider first the effects of regulation on insurer entry and exit decisions. To the extent that regulation reduces insurer returns below those available in other markets, firms will choose not to enter regulated markets. Concerns about future regulatory stringency may also deter entry if insurers must incur sunk investments to enter the market (Harrington, 1992). Sunk investments required of insurers include investments in state distribution and claims handling networks, advertising in local markets and costs of regulatory compliance in the state. The more stringent is regulation, and the larger are the necessary sunk investments, the greater will be the distortions to entry.

Incumbent firms in a market must decide whether to exit in response to stringent regulation. Of course, if regulatory stringency remains constant over time, firms which entered the market at some point in time should have no incentive to exit later. However, empirical evidence from the 1960s through the early 1980s suggests that the nature and stringency of rate regulation has changed over time from profit-increasing to profit-reducing (Pauly, Kleindorfer and Kunreuther, 1986; Grabowski, Viscusi and Evans, 1989). More recent evidence suggests that the trend toward more restrictive rate regulation may be continuing: in 1988 the state of California passed legislation which introduced prior approval regulation and mandated rate 
rollbacks for all insurers, and at least 14 other states have since considered similar measures. This increased regulatory stringency may drive incumbent firms out of the market. Withdrawal from regulated markets may be inhibited, however, by the existence of fixed, state-specific inputs to production. Important inputs into insurance production are labor, real capital and financial capital. In the short run, labor inputs may be variable, but capital inputs are generally fixed. What we term real capital includes investments in distribution networks and claims handling facilities, which are fixed in the short run. Financial capital incorporates surplus funds to bolster solvency, and is also fixed. Unlike real capital, however, financial capital is not tied to any one line of business or state market even in the short run. Thus, to the extent that labor and real capital inputs are in place, insurers can quickly and costlessly reallocate capacity across insurance markets by a simple reallocation of financial resources. Insurers may nevertheless be slow to withdraw entirely from a regulated market due to the fact that real capital resources are not mobile across markets in the short run.

There are also other factors at work in regulated insurance markets which imply that insurers' response to rate regulation may be to reduce market share rather than to exit the market. Regulators in many states have the ability to force insurers to pay explicit or implicit exit ransoms. For example, the courts have consistently upheld the ability of regulators to withdraw licenses for all business in the state if an insurer wishes to withdraw from a heavily regulated line such as automobile insurance. Some states also force withdrawing insurers to continue contributions to the residual market deficit for a period of time after withdrawal from the state. These actions will significantly raise exit costs for insurers in regulated markets, which may discourage or slow the pace of exit (Harrington, 1992). The extent to which these 
regulatory barriers raise the costs of exit will differ across firms, however. Firms which operate in more than one line of insurance in a state will be more reluctant to withdraw from even a stringently regulated auto insurance market if this action could threaten licenses to write other lines in the state.

Even if regulation is not sufficiently stringent to induce market exit, regulatory profit restrictions will lead to reductions in insurer output. The relative reliance on state-specific real capital inputs, and alternative opportunities for the use of financial capital, will determine differences in output reductions across insurers in response to regulation. These features together imply that low cost insurance producers, especially those with existing distribution systems in other states, should reduce output the most in the face of rate regulation. This is due to the ability of firms with lower production costs to achieve higher rates of return than other firms in the absence of restrictive regulation. Low cost producers therefore have higher opportunity costs of devoting resources to a regulated market for which rates of return are held below those achievable elsewhere.

This theoretical framework yields a set of predictions regarding the responses of firms faced with actual or potential regulatory constraints, and about how these responses will differ across firms. This leads to a number of implications for the aggregate effect of regulation on the resulting equilibrium market structure in a state. One hypothesis that can be drawn from the theory is that, all else equal, fewer firms will choose to operate in regulated state insurance markets, since entry is relatively unattractive and exit is relatively attractive in these markets.

Predictions regarding the relative numbers of different types of firms are less clear-cut. We might expect that the number of direct writers in regulated insurance markets will be 
relatively lower than the number of independent agency writers, because direct writing requires greater sunk investments in the market and hence their entry into regulated environments will be discouraged. However, once these investments have been made they will inhibit exit if the regulatory environment worsens, implying that direct writers may be more prevalent in regulated markets. On the other hand, firms using the independent agency system tend to be less specialized in automobile insurance than direct writers (Regan and Tennyson, 1994). This may slow their rate of exit from unfavorable market environments, since their lack of specialization implies greater costs of exit in terms of profits foregone in unregulated lines of insurance. National firms, especially those specializing in automobile insurance, may be quick to exit unprofitable auto insurance markets, because their costs of exit may be lowered due to their existing distribution networks elsewhere. However, these firms may in fact have less need to actually exit the market, since they can more cheaply reallocate financial resources to the most profitable state markets.

The above reasoning yields more definitive predictions about the relative market shares of these firms in regulated states. Greater diversity of exposures across lines of business in a state may increase the costs of reducing auto insurance market share if this adversely affects the insurer's reputation or relationships with sales agents. This implies that independent agency firms should be more reluctant to reduce output than direct writers or auto specialists in response to stringent regulation. We also expect the market shares of the large, low cost insurance producers to be lower in regulated markets, due to their greater ability to achieve higher rates of return in unregulated markets. A national distribution system may also make it especially easy for a firm to reduce markêt share in regulated states, since the firm can then simply 
reallocate financial resources to other state markets without new investments in real capital inputs. The (opportunity) costs of capacity reallocation may vary with the output mix of the insurer, however, and hence may be most observable in national firms which specialize in automobile insurance. This reasoning may also imply that direct writing firms have lower market shares in regulated states, since these firms tend to be low cost producers of automobile insurance.

\section{Market Structure in Regulated and Unregulated States}

The theoretical discussion above suggests a number of dimensions along which automobile insurance market structure may be distorted by the stringent regulation of rates. The remaining sections of the paper investigate the extent to which these predictions are borne out in the data, by examining the differences in market structure across regulated and unregulated states. The analysis is undertaken at the level of state aggregates, for all automobile insurance coverages combined. This section begins by examining data on the mean values of the number of firms and market shares by type of firm for regulated and unregulated states.

States are first grouped into two basic categories - regulated and unregulated. Consistent with previous studies, states which employ prior approval regulation, state-made rates or mandatory bureau rates are considered regulated; states employing regulatory systems which primarily require insurers to file rates rather than to obtain approval of rates are considered unregulated. The regulatory system employed in each state was determined from information obtained from the National Association of Insurance Commissioners, the Alliance of American Insurers, and personal contacts ${ }^{\circ}$ with state insurance departments in cases in which the 
appropriate categorization was ambiguous.

The state of California is omitted from the analysis because of the passage of Proposition 103 in late 1988. This controversial legislation introduced prior approval regulation of insurance rates, along with a number of other strict controls on the pricing practices and other activities of insurers in that state. Due to the lags inherent in implementation of these regulations, and to the continuing challenges of the legislation by insurers, it is unclear whether California should be considered regulated or unregulated in subsequent years. Our sample thus contains 25 regulated states and 24 unregulated states.

To further differentiate those states which are the most heavily regulated, we also classify five states which have extremely large residual markets for automobile insurance as states with "stringent" regulation. All states operate residual markets for automobile insurance, which are designed to provide at least minimal coverage to those individuals unable to obtain insurance in the private market. Previous studies have documented that stringent regulation of insurance rates is associated with large fractions of the population insured through these residual mechanisms (Grabowski, Viscusi and Evans, 1989). The five stringently regulated states in our sample are Massachusetts, New Hampshire, New Jersey, North Carolina and South Carolina. In each of these states at least 20 percent of drivers were insured in the residual market throughout the 1980s.

Table 2 compares summary measures of market structure for unregulated states, regulated states, and stringently regulated states. We first note that, consistent with intuition, the average number of firms selling automobile insurance is lower in regulated and stringently regulated states than in the unregulated statès. This difference is significant at the 10 percent confidence 
level for regulated versus unregulated states, and significant at the 1 percent confidence level for stringently regulated versus unregulated states. This comparison is particularly meaningful since the table also demonstrates that there are not significant differences in the average size of the auto insurance market across these sets of states, where size is measured by total written premium volume. Hence, the fact that there are fewer firms writing in regulated states markets is not attributable to differences in market size. This result also holds for each specific type of insurance seller: in every category, there are fewer firms operating in regulated and stringently regulated states than in unregulated states. This is what we would expect if differences in the number of firms operating in each state is due to differences in the incentives for market entry and exit.

The largest percentage reductions in number of firms are for direct writers and for auto specialists. Relative to unregulated states, on average there are 19 percent fewer direct writers and 18 percent fewer auto specialists in regulated states; in stringently regulated states there are 35 percent fewer direct writers and 37 percent fewer auto specialists. This compares to an 11 percent reduction in the total number of firms in regulated states, and a 23 percent reduction in the number of firms in stringently regulated states, relative to the unregulated state average. These results are consistent with the hypothesis that firms with relatively high proportions of business in the regulated line will be less likely to enter and more likely to exit when faced with profit restrictions. The results for direct writers may also reflect the effects on entry of greater sunk investments required for direct writing firms to enter a market.

The numbers of firms in the various "national" categories included in the table are reduced significantly by regulation and stringent regulation, but by less in percentage terms than 
the reduction in the total number of firms. This may reflect a greater tendency by these firms to reduce market share in relatively unprofitable markets rather than to exit. It may also be a consequence of the definition of national firms in our study, however, which requires that the firm sell auto insurance in a substantial number of states. This latter interpretation is supported by the fact that the number of the "big four" auto insurers (State Farm, Allstate, Nationwide and Farmers) is lower in regulated and stringently regulated states, and by a greater percentage than the reduction in the total number of firms. ${ }^{6}$

Similar to the findings on numbers of firms, direct writers also exhibit lower market shares in regulated and stringently regulated states. The largest market share reductions are for auto specialists and the "big four", however. This is consistent with the hypothesis that low cost producers have the greatest incentive to shift resources out of the market in response to regulatory profit restrictions.

Interestingly, the national categories of firms do not exhibit significantly lower market shares in regulated states, and national firms as a group actually have a significantly larger average market share in regulated and stringently regulated states than in unregulated states. This appears to be contrary to our theory, since national distribution systems should make it easy to reduce market share in response to regulation. Many of the national firms (57 of 78 ) use the independent agency system of selling, however, and hence may not be low cost producers of auto insurance. In addition, many independent agency firms write a significant fraction of their business in lines other than auto insurance, and hence may be constrained to offer auto insurance as a condition of keeping customers and agents satisfied. However, neither national direct writers nor national auto specialists exhibit significantly lower market shares in regulated states, 
indicating that the results could also be an artifact of the definition of national firms in our study. This possibility suggests the need for multivariate analysis to control for other relevant differences in state insurance markets.

\section{The Effects of Regulation on the Number of Sellers}

This section uses multiple regression analysis to further investigate the effects of regulation on the number of firms in each state. This approach allows us to more precisely isolate regulatory effects by controlling for other differences across state insurance markets which might be related to differences in the number of sellers. In addition, using regression analysis allows us to pool data over several years in order to estimate the effect of regulation on average over time rather than for a single year. This may be important if there is noise in the data in any given year, or if there are systematic effects on market structure by year (e.g., the insurance cycle) which may imply that a single year is unrepresentative of the true regulatory effects. The regression analysis is undertaken using annual data by state for the time period 1987 to 1992.

Due to concerns about transitional effects of regulatory changes on market structure, the models are estimated using data only for those states utilizing a consistent regulatory regime for our entire sample period, and for several years prior. We eliminate states which changed regulatory regimes subsequent to 1984 . The states eliminated from the sample under this reasoning are California, Florida, Georgia and New Mexico.?

Several alternative dependent variables are employed in the regressions. The basic hypothesis that regulation reduces incentives to sell in the state is tested by examining the total 
number of firms writing positive premiums in each state. We also estimate the effects of regulation on the number of several different types of firms, to investigate the effects of regulation on the relative incentives to operate in the market. . We estimate models for the number of direct writers, the number of national direct writers, the number of national firms in total, the number of national auto specialists, and the number of the "big four" auto producers operating in each state, since our theoretical discussion suggests that regulatory effects on the entry and output decisions may be greatest for these firms.

To test the hypothesis that regulation lowers the number of firms writing in the market, we define a regulation dummy variable which is equal to one if the state uses prior approval regulation, state-made rates or mandatory bureau rates. To allow for differences in regulatory stringency across states, and to test whether there are differences in regulatory effects between regulated states in general and those most stringently regulated, we include a dummy variable equal to one if a state has stringent regulation of rates. Stringent regulation is defined as in the previous section, to include those states for which the residual market constinted greater than 20 percent of the total insurance market throughout the decade of the 1980s. We expect this variable to be negatively related to the number of firms in the market.

The empirical model also includes several variables other than regulation which might be expected to influence the number of firms writing in the state. Key among these is the size of the state automobile insurance market. Differences across states in the potential size of the auto insurance market are controlled for by including the natural log of the number of registered automobiles in the state. All else equal, we expect to observe a larger number of firms writing in larger insurance markets. We include per capita income in the state as a measure of the level 
of demand for insurance and insurance services. We expect this variable to be positively related to the number of insurers in the market. The percentage of the population that moved into the state during the decade of the 1980 s is included in the model as an indicator of state growth and economic dynamism. We expect this variable to be positively related to the number of firms in the market, since high growth should attract entrants into the market, and less stable population composition may also provide opportunities for entrants.

The degree of market segmentation by distinct risk categories may also influence market structure. The primary rating factor used for automobile insurance is the geographic location of the insured vehicle, with different locations in the state assigned to different rating territories. We therefore include the number of standard rating territories per 1000 registered cars in the state (territory density) as a measure of market segmentation. We expect to observe more insurance firms operating in more segmented markets, and hence we expect a positive coefficient on the territory density variable. The relative locational density of the consuming population in the state may also help to determine the number of sellers in the market; this possibility is controlled for by including each state's population density, defined as resident population divided by land area, in the model. This variable should also be positively related to the number of firms in the market, since greater customer density should support greater numbers of firms.

The regression model also includes dummy variables for eight of the nine census divisions in the country, to control for potentially omitted regional influences on the number of firms in the market. Of particular concern is the possibility that regional differences in the tendency of states to regulate insurance markets, coupled with locational factors which may influence firms' entry decisions (e.g., distance from the firms' headquarters), may lead to 
spurious inferences regarding the effects of regulation on market structure. Including the regional variables in the model assures that the estimated regulatory effects are net of such locational influences. Finally, the model includes dummy variables for years 1988 through 1992, to allow for year-specific fixed effects on the numbers of firms in the market.

Summary statistics for all variables included in the regression analysis are reported in the data appendix. The results of the estimation are reported in Table 3. Consistent with our theoretical model, the number of firms in the market is significantly lower in regulated states, and even lower still in the stringently regulated states. After controlling for other features of the market, the marginal effect of regulation is to lower the number of firms in the market by 4.2 ; in stringently regulated states the average reduction in the number of firms is 28.4 . This amounts to a 3.9 percent reduction in the number of firms in regulated states, and a 26.3 percent reduction in stringently regulated states, relative to the unregulated state average.

Regulation also significantly reduces the number of each distinct type of firm in the market, and as expected, the reduction in the number of each type of firm is much larger in the stringently regulated states. This is also consistent with our theory: The effects of regulation are greatest for national auto specialists, relative to the mean number of these firms writing in unregulated states. This result is consistent with the argument that national auto specialists have particularly reduced incentives to operate in regulated states, since their low costs of insurance provision $^{8}$ and national distribution systems imply that they can earn higher returns than other insurers in unregulated markets. On average there are 6.1 percent fewer national specialist firms in regulated markets, and 24.9 percent fewer in the stringently regulated states, relative to the unregulated state average. 
As an alternative to using dummy variables to measure regulatory effects, we also try a continuous index of regulatory stringency in the models. This approach allows a more accurate measure of differences in regulatory stringency across states, avoiding problems associated with potential differences in the implementation of regulatory rules which are identical in law. ${ }^{9}$ The regulatory index is taken from Conning and Company surveys of insurance industry and regulatory executives (Conning and Company, 1987 and 1992). The survey asks each respondent to assign an index number (between 1 and 10) of competitive freedom to each state insurance market, where higher values indicate greater competitive freedom. The state indices are reached by averaging the individual responses. Previous analysis has shown this index to be highly correlated with indicators of the type of regulatory system in a state, and to be a better predictor of other measures of regulatory stringency (unit price and residual market size) than a simple regulatory dummy variable (Suponcic, 1994).

We have Conning ratings from surveys in 1986 and 1991 only. We utilize the 1986 value for the years 1987 through 1989, and use the 1991 value for 1990 through 1992 since the 1991 survey seems likely to reflect the regulatory environment in 1990 . The results of estimating the models using the Conning index instead of the regulation dummy variables are presented in Table 4. The results support the inferences drawn from Table 3. Greater competitive freedom, as represented by a higher Conning rating, is associated with larger numbers of firms of all types in the market. Unlike the results using the regulatory dummy variable, the largest percentage effect of the Conning index on the number of firms in the market occurs in the all-firms regression. This is consistent with the results of the previous model with respect to stringently regulated states, and may reflect the fact that the Conning index 
incorporates both the existence of regulation and its stringency into a single variable. This analysis suggests that large, low cost national firms may choose to reduce market share rather than to exit regulated markets. This hypothesis is explored further in the next section.

One potential criticism of the preceding analysis is the likelihood that regulatory stringency in a state is itself partially determined by the industrial structure of the market. To the extent that differences in regulatory stringency across states reflects the relative success of firms in influencing the regulatory outcome, this will be likely to depend upon the types of firms that write in the state market. Previous empirical analysis supports the view that regulatory stringency, as measured by the average unit price in a state's auto insurance market, is affected by variables proxying the relative ability of consumer and industry groups to influence the regulatory outcome (Cummins, Phillips and Tennyson, 1994).

To control for the possible endogeneity of regulatory stringency, we estimate the models using two stage least squares, treating the Conning index as an endogenous variable. Instruments employed in the analysis are the budget of the state insurance commission, and the premium taxes collected from insurance firms in each state, in total and on a per firm basis; and a dummy variable indicating whether the state's insurance commissioner is elected or appointed. These variables should be correlated with the stringency of the regulatory outcome in a state, but not due to political influence related to industry structure. The two stage least squares (2SLS) estimation results are reported in Table 5. The estimates are very similar to the ordinary least squares (OLS) estimates reported in Table 4, indicating that our conclusions are robust to the possibility that regulatory stringency and industry structure are simultaneously determined. 


\section{The Effects of Regulation on Market Shares}

This section estimates the effect of regulation on the market shares of selected groups of insurers. Empirical models are developed for dependent variables measuring the share of each state's automobile insurance market written by the groups of firms examined above: direct writers, national writers, national direct writers, national auto specialists and the "big four". Because market shares of necessity lie between zero and one, the dependent variables used are the log-odds ratios of market shares $\ln ($ share/(1-share)). This transformation ensures that the predicted values of market shares from the least squares regressions lie between zero and one.

Control variables included in the market share models are state per capita income and population density, the proportion of the population which moved into the state between 1980 and 1990 , and the ratio of automobile bodily injury claims to property damage claims in the state. Most of these variables were also included in the number of firms regressions, and are expected to have the same signs in the market share models, but may have different interpretations here because analysis of market shares implies any influence of these variables must reflect how the decisions of these firms are affected relative to those of other firms.

Higher per capita income should indicate a higher level of insurance demand; this should be positively related to the market shares of these low cost firms since they should devote more resources to relatively attractive markets. However, previous studies have argued that higher income will lead to greater demand for services from insurers, suggesting that low price (low service) firms may not capture as much of the market in high income states (Pauly, Kleindorfer and Kunreuther, 1986). Hence, we have no strong priors about the sign of the coefficient on this variable. 
Population density should be positively related to the market shares of both direct writers and large national firms, since these firms are more likely to rely on mass advertising to obtain customers. ${ }^{10}$ Similarly, the percentage of the population which recently moved into the state should give national and brand name insurers a marketing advantage, and hence increase their market share. The bodily injury claims variable is added to this set of models as a measure of the relative riskiness of auto insurance in the state. Since bodily injury liability claims are the most expensive and unpredictable component of auto insurance claims, a higher rate of bodily injury claims may lead insurers to reduce their exposure in the market. The impact of these claims on relative output levels across insurers will depend upon their relative expertise in underwriting and settling these claims. This makes strong predictions difficult at the level of aggregation in this study. However, if there are economies of scale with respect to underwriting and settlement of liability claims this would imply that the market shares of the largest firms should be positively related to the rate of bodily injury claims.

As in the previous section, we estimate three versions of each model: the first using dummy variables to measure the effects of regulation, the second using the Conning index of competitive freedom in an OLS regression and the final model employing 2SLS estimation allowing the Conning index to be endogenously determined.

The OLS regressions with regulation dummy variables are reported in Table 6. The results indicate relatively weak effects of regulation on the market shares of the five groups of firms studied. The regulatory dummy variable is not significantly related to the market shares of national direct writers, national auto specialists or the "big four". For national firms as a group, the regulation dummy variable has the opposite sign from that expected. This latter 
finding may be due to the fact that most of the national insurers market through independent agents. Thus, we expect that their reduction in output in response to regulation will be lower than that of direct writing firms or other low cost producers; this implies an increase in net market share for these firms in regulated states.

All five groups of firms exhibit significantly lower market shares in the most stringently regulated states, however. This finding is consistent with our theoretical arguments, and the results overall are consistent with previous studies which have found only modest effect of regulation in most states, with only a few states apparently enforcing regulation of an economically significant magnitude. Nonetheless, as shown in Tables 7 and 8 , all five groups of firms do exhibit significantly greater market shares in states receiving a higher Conning index of competitive freedom. This suggests that the lack of significance of the regulatory dummy variable may be due to its inability to capture differences in regulatory stringency across states.

The Conning index is positive and strongly significant for all groups of firms in the OLS regressions and for all groups of firms except the national writers in the 2SLS regressions. The 2SLS results in Table 8 demonstrate that the largest effects on market share of a one point increase in the index occurs for the "big four" auto producers and the national auto specialists. This is consistent with the hypothesis that low cost, national producers will have the greatest incentive to reduce output in states which use regulation to limit insurers' profitability.

$$
\begin{gathered}
- \text { Tasio } \\
\text { T. } 0
\end{gathered}
$$

\section{Conclusion}

This paper has argued that restrictive regulation of auto insurance rates will distort the industrial structure of the market through its effects on insurers' entry and output decisions. The 
empirical evidence presented in the paper suggests that this is the case, especially in those states which enforce the most stringent rate regulation. The data suggest that increased regulatory stringency lowers the number of firms selling in the market, and also lowers the number of low cost and national producers in the market. The market shares of low cost and national producers are also significantly lowered by increased regulatory stringency. These results hold even after controlling for other factors which may influence the relative prevalence of these firms in the market, such as market size, density and growth, consumer income and regional effects. The results are also robust to the assumption that regulatory stringency in the state is itself partially determined by the number and market shares of these firms.

While normative assessments of regulatory policies lie beyond the scope of this analysis, our findings suggest that regulation could have adverse unintended effects on consumer welfare by raising insurance prices. If the firms that achieve the largest size or that specialize most heavily in automobile insurance in unregulated markets are the lowest cost producers of this insurance, then the decline in their relative market presence under regulation will raise the average price of insurance paid by consumers.

Much remains to be done to understand properly the effects of regulation on the industrial structure of auto insurance markets. One potentially fruitful approach would be to examine changes in market structure in the aftermath of changes in regulatory stringency. Further insights into the causes and consequences of the market structure differences across regulated and unregulated states could also be garnered from analyzing entry, exit and market shares at the firm or group level. Use of this more detailed data would allow for controls related to the specific characteristics of each firm, rather than the average characteristics of generic categories 
of insurers. Given the great variation in size and specialization across firms identified in this paper, examining data at the firm level may be particularly important to providing a comprehensive assessment of regulatory effects on insurance markets. 
1.See Harrington (1984) and Grabowski, Viscusi and Evans (1989) for comprehensive reviews of the literature.

2.Joskow (1973) investigated the effects of regulation on the market shares of firms which use exclusive sales agents ("direct writers"), a lower-cost automobile insurance distribution system than the traditional independent agency system. His maintained hypothesis, however, was that rate regulation promotes collusive pricing by insurers (and hence raises unit prices).

3. Best Company lists a total of 570 groups and independent sellers of private passenger automobile insurance; however, some of these firms reported zero or negative premiums for this line and are omitted from the analysis.

4.These differences are likely to be related to the differences in organizational structure, due to the resulting differences in cost structures and production technologies. For empirical evidence on the relationship between insurer organization structure and market positioning see Mayers and Smith, 1988; Marvel, 1982; Regan and Tennyson, 1994.

5.Under the standard categorization popularized by Best Company reports, 40 firms are known as "national" insurance writers. However, this categorization is not based on automobile insurance writings: Not all of these carriers sell auto insurance nationally, and there are a significant number of insurers categorized by Best's as "regional" who do write nationally. We feel that our definition of national sellers is superior for purposes of analyzing the auto insurance market.

6.This is due largely to the fact that Farmers writes auto insurance only in 32 states, spanning 6 census divisions; thus, by our definition Farmers is not a "national" auto insurer. Farmers does not write in many eastern stạtes, and these states are more likely to be regulated than those 
in other regions. This leaves open the question of whether Farmers' entry decisions are motivated by regional issues or by regulation; this is addressed further in the regression analysis below.

7.Similar results, available from the authors, are obtained when all states are included in the analysis. We nevertheless excluded the transitional states because we want to consider the equilibrium effects of regulation on the industry configuration.

8.An examination of the automobile insurance expense ratios of these firms confirms that their expenses are lower than the national average over all firms.

9.Previous studies have found that the effect and effectiveness of rate regulation may vary across regulated states ostensibly utilizing identical regulatory systems (Harrington, 1987; Grabowski, Viscusi and Evans, 1989).

10.See Marvel (1982) for a theoretical analysis of why direct writers are more likely to use mass advertising than independent agency writers. 
Suponcic and Tennyson

\section{References}

Barrese, James and Jack M. Nelson (1992). "Independent and Exclusive Agency Insurers: A Reexamination of the Cost Differential." Journal of Risk and Insurance 59: 375-397.

Conning and Company (1987). Regulatory Survey of the Property-Casualty Industry. Hartford. Conning and Company.

(1992). Regulatory Survey of the Property-Casualty Industry. Hartford.

Conning and Company.

Cummins, J. David and Sharon Tennyson (1992). "Controlling Automobile Insurance Costs." Journal of Economic Perspectives 6: 95-115.

Richard Phillips and Sharon Tennyson (1993). "Interest Group Pressure and the Regulatory Outcome in Automobile Insurance." Working paper. University of Pennsylvania. and Jack Vanderhei (1979). "A Note on the Relative Efficiency of PropertyLiability Insurance Distribution Systems." Bell Journal of Economics 10: 709-719.

Frech, H. and J. Samprone (1980). "The Welfare Loss of Excess Nonprice Competition: The Case of Property-Liability Insurañce Regulation." Journal of Law and Economics 23: 429-440. 
Grabowski, Henry, W. Kip Viscusi and William N. Evans (1989). "The Price and Availability Trade-offs of Automobile Insurance Regulation." Journal of Risk and Insurance 56: 275-299.

Harrington, Scott (1984). "The Impact of Rate Regulation on Prices and Underwriting Results in Property-Liability Insurance: A Survey." Journal of Risk and Insurance 51: 577-623.

(1987). "The Impact of Rate Regulation on Auto Insurance Loss Ratios:

Some New Evidence." Journal of Insurance Regulation 5: 182-202.

(1992). "Rate Suppression." Journal of Risk and Insurance 59: 185-202.

Ippolito, Richard (1979). "The Effects of Price Regulation in the Automobile Insurance Industry." Journal of Law and Economics 22: 55-89.

Joskow, Paul (1973). "Cartels, Competition and Regulation in the Property-Liability Insurance Industry." Bell Journal of Economics and Management Science 4: 375-427.

Klein, Robert (1989). "Competition in Private Passenger Automobile Insurance: A Report to the NAIC Personal Lines Committee". Internal report, National Association of Insurance Commissioners. Kansas City, MO.

Kramer, Orin (1992). "Rate Suppression, Rate-of-Return Regulation, and Solvency." Journal of 
Insurance Regulation 10: 523-563.

Marvel, Howard (1982). "Exclusive Dealing." Journal of Law and Economics 25: 1-25.

Mayers, David and Clifford W. Smith (1988). "Ownership Structure Across Lines of PropertyCasualty Insurance. " Journal of Law and Economics 31: 351-378.

Pauly, Mark, Paul Kleindorfer and Howard Kunreuther (1986). "Regulation and Quality Competition in the U.S. Insurance Market." In Finsanger, Jorg and Mark Pauly, eds., The Economics of Insurance Regulation. New York: St. Martins Press.

Regan, Laureen and Sharon Tennyson (1994). "Agent Discretion and the Choice of Insurance Marketing System." Working paper. University of Pennsylvania.

Suponcic, S.J. (1994). "Regulatory Stringency in Automobile Insurance." Working paper. University of Pennsylvania. 
Suponcic and Tennyson

\section{Data Appendix}

This appendix provides the precise definition of and documents the data source used to obtain each explanatory variable used in the regression analysis. It also reports the mean and standard deviation of these variables over the sample period 1987-1992. All dependent variables used in the analysis were obtained from A.M. Best Company data tapes for Best's Executive Data Service. The other variable definitions and sources are as follows:

Number of Registered Autos: the number of privately owned motor vehicles registered in the state. Source: U.S. Department of Transportation, Highway Statistics.

Per Capita Income: total income per capita in the state. Source: U.S. Department Commerce, Statistical Abstract of the United States.

Population Density: resident population per square mile of land area in the state. Source: U.S. Department Commerce, Statistical Abstract of the United States.

Territory Density: the number of rating territories employed by the major statistical rating agency in the state, divided by the number of registered automobiles in the state. Source for rating territories: Insurance Research Council, Trends in Auto Bodily Injury Claims.

Percent Movers: the fraction of the state's resident population in 1990 who lived in a different state in 1980. Source: U.S. Department Commerce, Statistical Abstract of the United States. Bodily Injury Claims: the number of automobile bodily injury liability insurance claims incurred in the state divided by the number of automobile property damage liability insurance claims paid in the state. Source: National Association of Independent Insurers, FastTrack Monitoring System database.

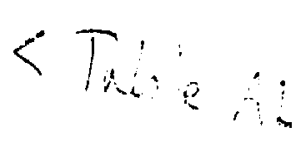


TABLE 1

Private Passenger Automobile Insurance

Market Statistics

1989 Data

\begin{tabular}{lccc} 
& National Market & \multicolumn{2}{c}{ State Markets } \\
& & Mean & Std. Dev. \\
\hline Total Premiums & & & \\
Unit Price & $74,399,743,314$ & $1,485,019,174$ & $1,930,625,557$ \\
& 1.33 & 1.37 & 0.13 \\
Number of Firms & & & \\
Total & & & \\
Direct Writers & 526 & 103.38 & 26.00 \\
National Firms & 101 & 27.88 & 6.71 \\
National Direct Writers & 78 & 62.64 & 7.89 \\
Auto Specialists & 21 & 18.62 & 2.47 \\
National Auto Specialists & 233 & 34.18 & 11.40 \\
"Big Four" & 20 & 16.98 & 2.39 \\
& 4 & 3.54 & 0.50 \\
Market Shares & & & \\
Direct Writers & & & \\
National Firms & 0.646 & 0.642 & 0.117 \\
National Direct Writers & 0.697 & 0.701 & 0.125 \\
Auto Specialists & 0.476 & 0.481 & 0.139 \\
National Auto Specialists & 0.677 & 0.654 & 0.119 \\
"Big Four" & 0.432 & 0.431 & 0.113 \\
& 0.417 & 0.424 & 0.134 \\
Measures of Concentration & & & \\
C4 & & & \\
HHI & 0.417 & 0.540 & 0.086 \\
& 659 & 1043 & 311.66 \\
& & & \\
\hline
\end{tabular}

Source: A. M. Best Company Reports, 1989 
TABLE 2

Private Passenger Automobile Insurance

Statistics by State Regulatory Status

1989 Data

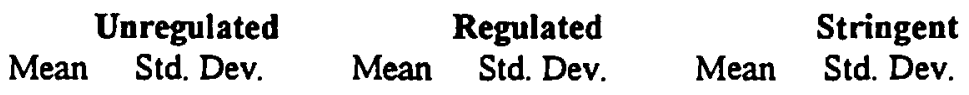

Total Premium

$1,087,894,971 \quad 863,030,024$

$1,474,385,267 \quad 1,575,868,978$

$1,429,382,568 \quad 791,092,965$

Unit Price

1.39

0.13

1.34

0.14

$1.23^{*}$

0.18

Number of Firms

Total

$\begin{array}{rr}108.24 & 22.56 \\ 30.60 & 5.28 \\ 64.44 & 4.73 \\ 19.40 & 1.41 \\ 37.20 & 9.55 \\ 17.72 & 1.54 \\ 3.76 & 0.44\end{array}$

$\begin{array}{lr}96.71^{*} & 27.80 \\ 24.75^{* * *} & 6.81 \\ 60.38^{* *} & 9.82 \\ 17.75^{* * *} & 3.07 \\ 30.46^{* *} & 12.22 \\ 16.13^{* * *} & 2.85 \\ 3.29^{* * *} & 0.46\end{array}$

$83.00^{* * *} \quad 12.73$

Direct Writers

National Firms

National Direct Writers

Auto Specialists

0.679

0.084

$0.599 * *$

0.133

$0.520^{* *}$

0.150

National Firms

0.670

0.107

$0.741^{* *}$

0.159

$0.732^{* *}$

0.043

National Direct Writers

0.476

0.100

0.491

0.150

0.465

0.116

Auto Specialists

0.711

0.069

$0.588^{* * *} \quad 0.126$

$0.541 * * * 0.095$

National Auto Specialists

0.440

0.092

0.424

0.134

0.375

0.155

0.459

0.100

$0.386^{* *}$

0.157

$0.279 * *$

0.167

Measures of Concentration

C4

0.562

0.058
221.33

$0.518 * * 0.106$

$0.454^{* *} \quad 0.087$

HHI

1111.57

977.19* 380.95

$756.47 * * * 219.97$

***significantly different from unregulated states at .01 level, one-sided test.

**significantly different from unregulated states at .05 level, one-sided test.

*significantly different from unregulated states at .10 level, one-sided test. 


\section{TABLE 3}

1987 - 1992 Data by State

Consistently Regulated States

Ordinary Least Squares Estimation

Number of Firms

\begin{tabular}{|c|c|c|c|c|c|c|}
\hline & $\begin{array}{l}\text { Total } \\
\text { Firms }\end{array}$ & $\begin{array}{l}\text { Direct } \\
\text { Writers }\end{array}$ & $\begin{array}{l}\text { National } \\
\text { Firms }\end{array}$ & $\begin{array}{l}\text { National } \\
\text { Direct } \\
\text { Writers }\end{array}$ & $\begin{array}{l}\text { National } \\
\text { Auto } \\
\text { Specialists }\end{array}$ & $\begin{array}{l}\text { Big } \\
\text { Four }\end{array}$ \\
\hline Intercept & $\begin{array}{l}-213.2514^{* * *} \\
(16.5202)\end{array}$ & $\begin{array}{l}-39.8104 * * * \\
(5.6440)\end{array}$ & $\begin{array}{l}-38.1102^{* * *} \\
(6.8912)\end{array}$ & $\begin{array}{l}-2.0722 \\
(2.6345)\end{array}$ & $\begin{array}{l}-4.0549 \\
(2.5040)\end{array}$ & $\begin{array}{l}1.2556^{* * *} \\
(0.4522)\end{array}$ \\
\hline Log Registered Autos & $\begin{array}{l}21.3750^{* * *} \\
(1.1467)\end{array}$ & $\begin{array}{l}4.7397^{* * *} \\
(0.3918)\end{array}$ & $\begin{array}{l}6.8609^{* * *} \\
(0.4783)\end{array}$ & $\begin{array}{l}1.4975^{* * *} \\
(0.1829)\end{array}$ & $\begin{array}{l}1.5953^{* * *} \\
(0.1738)\end{array}$ & $\begin{array}{l}0.1811^{* * *} \\
(0.0314)\end{array}$ \\
\hline Per Capita Income & $\begin{array}{l}-2.62 \mathrm{E}-3^{* * * *} \\
(4.63 \mathrm{E}-4)\end{array}$ & $\begin{array}{l}-6.60 \mathrm{E}-4^{* * * *} \\
(1.58 \mathrm{E}-4)\end{array}$ & $\begin{array}{l}-9.74 \mathrm{E}-4^{* * *} \\
(1.93 \mathrm{E}-4)\end{array}$ & $\begin{array}{l}-3.69 \mathrm{E}-4^{* * *} \\
(7.38 \mathrm{E}-5)\end{array}$ & $\begin{array}{l}-4.10 \mathrm{E}-4^{* * * *} \\
(7.01 \mathrm{E}-5)\end{array}$ & $\begin{array}{l}-4.43 \mathrm{E}-5^{* * * *} \\
(1.27 \mathrm{E}-5)\end{array}$ \\
\hline Population Density & $\begin{array}{l}12.9994^{* * *} \\
(4.9916)\end{array}$ & $\begin{array}{l}3.8516^{* *} \\
(1.7053)\end{array}$ & $\begin{array}{l}6.7494^{* * *} \\
(2.0822)\end{array}$ & $\begin{array}{l}2.0129^{* *} \\
(0.7960)\end{array}$ & $\begin{array}{c}1.4651^{*} \\
(0.7566)\end{array}$ & $\begin{array}{c}0.1788 \\
(0.1366)\end{array}$ \\
\hline Territory Density & $\begin{array}{l}1259.5890^{* * *} \\
(254.8785)\end{array}$ & $\begin{array}{l}377.9420^{* * *} \\
(87.0769)\end{array}$ & $\begin{array}{l}425.4940^{* * *} \\
(106.3193)\end{array}$ & $\begin{array}{l}144.6210^{* * *} \\
(40.6453)\end{array}$ & $\begin{array}{l}127.4190^{* * *} \\
(38.6330)\end{array}$ & $\begin{array}{l}11.9130^{*} \\
(6.9771)\end{array}$ \\
\hline Percent Movers & $\begin{array}{l}1.4340^{* * *} \\
(0.2592)\end{array}$ & $\begin{array}{l}0.2668^{* * *} \\
.(0.0885)\end{array}$ & $\begin{array}{l}0.3912^{* * *} \\
(0.1081)\end{array}$ & $\begin{array}{l}0.0917^{* *} \\
(0.0413)\end{array}$ & $\begin{array}{l}0.1213^{* * *} \\
(0.0393)\end{array}$ & $\begin{array}{l}0.0198^{* * * *} \\
(0.0071)\end{array}$ \\
\hline Rate Regulation & $\begin{array}{l}-4.1802^{* *} \\
(1.7350)\end{array}$ & $\begin{array}{c}-1.0369^{*} \\
(0.5927)\end{array}$ & $\begin{array}{l}-2.7109^{* * *} \\
(0.7237)\end{array}$ & $\begin{array}{l}-1.0262 * * * \\
(0.2767)\end{array}$ & $\begin{array}{l}-1.0794^{* * *} \\
(0.2630)\end{array}$ & $\begin{array}{l}-0.0404 \\
(0.0475)\end{array}$ \\
\hline Stringent Regulation & $\begin{array}{l}-24.3015^{* * *} \\
(2.5436)\end{array}$ & $\begin{array}{l}-6.1551^{* * *} \\
(0.8690)\end{array}$ & $\begin{array}{l}-11.3949^{* * *} \\
(1.0610)\end{array}$ & $\begin{array}{l}-3.5025^{* * *} \\
(0.4056)\end{array}$ & $\begin{array}{l}-3.3271^{* * *} \\
(0.3855)\end{array}$ & $\begin{array}{l}-0.2028^{* * *} \\
(0.0696)\end{array}$ \\
\hline Adjusted R-sq & 0.8115 & 0.7174 & 0.7158 & 0.5437 & 0.5684 & 0.7112 \\
\hline
\end{tabular}

Standard errors in parentheses. The model also includes year and census division dummy variables not reported here.

*** significant at the .01 level.

** significant at the .05 level.

* significant at the .10 level. 
TABLE 4

1987 - 1992 Data by State

Consistently Regulated States

Ordinary Least Squares Estimation

Number of Firms

\begin{tabular}{|c|c|c|c|c|c|c|}
\hline & $\begin{array}{l}\text { Total } \\
\text { Firms }\end{array}$ & $\begin{array}{l}\text { Direct } \\
\text { Writers }\end{array}$ & $\begin{array}{l}\text { National } \\
\text { Firms }\end{array}$ & $\begin{array}{l}\text { National } \\
\text { Direct } \\
\text { Writers }\end{array}$ & $\begin{array}{l}\text { National } \\
\text { Auto } \\
\text { Specialists }\end{array}$ & $\begin{array}{l}\text { Big } \\
\text { Four }\end{array}$ \\
\hline Intercept & $\begin{array}{l}-274.4419^{* * *} \\
(16.1954)\end{array}$ & $\begin{array}{l}-55.5083^{* * *} \\
(5.7129)\end{array}$ & $\begin{array}{l}-55.3340^{* * * *} \\
(8.0952)\end{array}$ & $\begin{array}{l}-8.3343^{* * *} \\
(2.9806)\end{array}$ & $\begin{array}{l}-11.2839^{* * *} \\
(2.7693)\end{array}$ & $\begin{array}{c}0.6134 \\
(0.4713)\end{array}$ \\
\hline Log Registered Autos & $\begin{array}{l}23.0092^{* * *} \\
(1.0720)\end{array}$ & $\begin{array}{l}5.1640^{* * *} \\
(0.3781)\end{array}$ & $\begin{array}{l}7.0532^{* * *} \\
(0.5358)\end{array}$ & $\begin{array}{l}1.5961^{* * *} \\
(0.1973)\end{array}$ & $\begin{array}{l}1.7465^{* * *} \\
(0.1833)\end{array}$ & $\begin{array}{l}0.2008^{* * *} \\
(0.0312)\end{array}$ \\
\hline Per Capita Income & $\begin{array}{l}-2.42 E-3^{* * *} \\
(4.23 E-4)\end{array}$ & $\begin{array}{l}-6.10 \mathrm{E}-4^{* * *} \\
(1.49 \mathrm{E}-4)\end{array}$ & $\begin{array}{c}-7.78 \mathrm{E}-4^{* * *} \\
(2.11 \mathrm{E}-4)\end{array}$ & $\begin{array}{l}-3.13 E-4^{* * *} \\
(7.79 E-5)\end{array}$ & $\begin{array}{l}-3.65 E-4^{* * *} \\
(7.23 E-5)\end{array}$ & $\begin{array}{l}-4.35 E-5 * * * \\
(1.23 E-5)\end{array}$ \\
\hline Population Density & $\begin{array}{l}15.8171^{* * *} \\
(4.6285)\end{array}$ & $\begin{array}{l}4.6064^{* * *} \\
(1.6327)\end{array}$ & $\begin{array}{l}5.9118^{* *} \\
(2.3135)\end{array}$ & $\begin{array}{l}1.8341^{* *} \\
(0.8518)\end{array}$ & $\begin{array}{c}1.4602^{*} \\
(0.7914)\end{array}$ & $\begin{array}{c}0.2214 \\
(0.1347)\end{array}$ \\
\hline Territory Density & $\begin{array}{l}1307.3540^{* * *} \\
(235.6606)\end{array}$ & $\begin{array}{l}390.6470^{* * *} \\
(83.1289)\end{array}$ & $\begin{array}{l}417.7590^{* * *} \\
(117.7936)\end{array}$ & $\begin{array}{l}142.3630^{* * *} \\
(43.3715)\end{array}$ & $\begin{array}{l}126.8570^{* * *} \\
(40.2960)\end{array}$ & $\begin{array}{l}12.5230^{*} \\
(6.8573)\end{array}$ \\
\hline Percent Movers & $\begin{array}{l}1.2683^{* * *} \\
(0.2335)\end{array}$ & $\begin{array}{l}0.2257 * * * \\
(0.0824)\end{array}$ & $\begin{array}{c}0.2636^{* *} \\
(0.3)(1)\end{array}$ & $\begin{array}{c}0.0569 \\
(0.0430)\end{array}$ & $\begin{array}{l}0.0940^{* *} \\
(0.0399)\end{array}$ & $\begin{array}{l}0.0190^{* * *} \\
(0.0068)\end{array}$ \\
\hline Competitive Freedom & $\begin{array}{l}6.5904^{* * *} \\
(0.4958)\end{array}$ & $\begin{array}{l}1.6851^{* * *} \\
(0.1749)\end{array}$ & $\begin{array}{l}2.2224^{*} \\
(0.2478)\end{array}$ & $\begin{array}{l}0.7341^{* * *} \\
(0.0912)\end{array}$ & $\begin{array}{l}0.7779^{* * *} \\
(0.0848)\end{array}$ & $\begin{array}{l}0.0637^{* * *} \\
(0.0144)\end{array}$ \\
\hline Adjusted R-sq & 0.8389 & 0.7425 & 0.6513 & 0.4806 & 0.5306 & 0.7211 \\
\hline
\end{tabular}

Standard errors in parentheses. The model also includes year and census division dummy variables not reported here.

*** significant at the .01 level.

** significant at the .05 level.

* significant at the .10 level. 


\section{TABLE 5}

1987 - 1992 Data by State

Consistently Regulated States

Two Stage Least Squares Estimation

Number of Firms

\begin{tabular}{|c|c|c|c|c|c|c|}
\hline & $\begin{array}{l}\text { Total } \\
\text { Firms }\end{array}$ & $\begin{array}{l}\text { Direct } \\
\text { Writers }\end{array}$ & $\begin{array}{l}\text { National } \\
\text { Firms }\end{array}$ & $\begin{array}{l}\text { National } \\
\text { Direct } \\
\text { Writers }\end{array}$ & $\begin{array}{l}\text { National } \\
\text { Auto } \\
\text { Specialists }\end{array}$ & $\begin{array}{l}\text { Big } \\
\text { Four }\end{array}$ \\
\hline Intercept & $\begin{array}{l}-330.1994^{* * *} \\
(21.4077)\end{array}$ & $\begin{array}{l}-58.9671^{* * *} \\
(6.8784)\end{array}$ & $\begin{array}{l}78.2276^{* * *} \\
(10.4954)\end{array}$ & $\begin{array}{l}-11.6376^{* * *} \\
(3.6133)\end{array}$ & $\begin{array}{l}-16.9182^{* * *} \\
(3.4483)\end{array}$ & $\begin{array}{c}0.9315 \\
(0.5679)\end{array}$ \\
\hline Log Registered Autos & $\begin{array}{l}25.4448^{* * *} \\
(1.2917)\end{array}$ & $\begin{array}{l}5.2867^{* * *} \\
(0.4109)\end{array}$ & $\begin{array}{l}8.1737 * * * \\
(0.6333)\end{array}$ & $\begin{array}{l}1.7815^{* * *} \\
(0.2180)\end{array}$ & $\begin{array}{l}2.0253^{* * *} \\
(0.2081)\end{array}$ & $\begin{array}{l}0.1893^{* * * *} \\
(0.0343)\end{array}$ \\
\hline Per Capita Income & $\begin{array}{l}-2.42 \mathrm{E}-3^{* * * *} \\
(5.12 \mathrm{E}-4)\end{array}$ & $\begin{array}{l}-5.69 \mathrm{E}-4^{* * * *} \\
(1.65 \mathrm{E}-4)\end{array}$ & $\begin{array}{l}-9.91 \mathrm{E}-4^{* * * *} \\
(2.51 \mathrm{E}-4)\end{array}$ & $\begin{array}{l}-3.81 \mathrm{E}-4^{* * * *} \\
(8.65 \mathrm{E}-5)\end{array}$ & $\begin{array}{l}-4.17 \mathrm{E}-4^{* * *} \\
(8.25 \mathrm{E}-5)\end{array}$ & $\begin{array}{l}-4.72 \mathrm{E}-5 * * * \\
(1.36 \mathrm{E}-5)\end{array}$ \\
\hline Population Density & $\begin{array}{l}23.3464^{* * *} \\
(5.3926)\end{array}$ & $\begin{array}{l}4.8597^{* * *} \\
(1.7131)\end{array}$ & $\begin{array}{l}9.7700^{* * *} \\
(2.6438)\end{array}$ & $\begin{array}{l}2.5303^{* * *} \\
(0.9102)\end{array}$ & $\begin{array}{l}2.4132^{* * *} \\
(0.8686)\end{array}$ & $\begin{array}{c}0.1924 \\
(0.1431)\end{array}$ \\
\hline Territory Density & $\begin{array}{l}1334.7260^{* * *} \\
(264.7600)\end{array}$ & $\begin{array}{l}391.2290^{* * *} \\
(84.9660)\end{array}$ & $\begin{array}{l}469.7680^{* * *} \\
(129.8020)\end{array}$ & $\begin{array}{l}156.2280^{* * *} \\
(44.6880)\end{array}$ & $\begin{array}{l}138.4510^{* * *} \\
(42.6470)\end{array}$ & $\begin{array}{l}13.0000^{*} \\
(7.0236)\end{array}$ \\
\hline Percent Movers & $\begin{array}{l}1.3766^{* * *} \\
(0.2681)\end{array}$ & $\begin{array}{l}0.2225 * * \\
(0.0858)\end{array}$ & $\begin{array}{l}0.3773^{* * *} \\
(0.1315)\end{array}$ & $\begin{array}{l}0.0855 * \\
(0.0453)\end{array}$ & $\begin{array}{l}0.1219^{* * *} \\
(0.0432)\end{array}$ & $\begin{array}{l}0.0196^{* * *} \\
(0.0071)\end{array}$ \\
\hline Competitive Freedom & $\begin{array}{l}10.4217^{* * *} \\
(0.9629)\end{array}$ & $\begin{array}{l}1.9514^{* * *} \\
(0.3132)\end{array}$ & $\begin{array}{l}3.8325^{* * *} \\
(0.4721)\end{array}$ & $\begin{array}{l}0.9738^{* * *} \\
(0.1625)\end{array}$ & $\begin{array}{l}1.1757^{* * *} \\
(0.1551)\end{array}$ & $\begin{array}{c}0.0426^{*} \\
(0.0255)\end{array}$ \\
\hline Adjusted R-sq & 0.8074 & 0.7278 & 0.6198 & 0.4612 & 0.5045 & 0.7091 \\
\hline
\end{tabular}

Standard errors in parentheses. The model also includes year and census division dummy variables not reported here.

*** significant at the .01 level.

** significant at the .05 level.

* significant at the .10 level. 


\section{TABLE 6}

1987 - 1992 Data by State

Consistently Regulated States

Ordinary Least Squares Estimation

Log - Odds Market Shares

\begin{tabular}{|c|c|c|c|c|c|}
\hline & $\begin{array}{l}\text { Direct } \\
\text { Writers }\end{array}$ & $\begin{array}{l}\text { National } \\
\text { Firms }\end{array}$ & $\begin{array}{c}\text { National } \\
\text { Direct } \\
\text { Writers }\end{array}$ & $\begin{array}{l}\text { National } \\
\text { Auto } \\
\text { Specialists }\end{array}$ & $\begin{array}{l}\text { Big } \\
\text { Four }\end{array}$ \\
\hline Intercept & $\begin{array}{l}-0.2591 \\
(0.2203)\end{array}$ & $\begin{array}{l}-0.2274 \\
(0.3850)\end{array}$ & $\begin{array}{l}-0.5606^{* *} \\
(0.2533)\end{array}$ & $\begin{array}{l}-0.6844^{* * *} \\
(0.2478)\end{array}$ & $\begin{array}{l}-0.1556^{* * *} \\
(0.2975)\end{array}$ \\
\hline Per Capita Income & $\begin{array}{l}2.09 \mathrm{E}-5 \\
(1.30 \mathrm{E}-5)\end{array}$ & $\begin{array}{l}1.18 \mathrm{E}-4^{* * *} \\
(2.26 \mathrm{E}-5)\end{array}$ & $\begin{array}{l}2.38 \mathrm{E}-5 \\
(1.49 \mathrm{E}-5)\end{array}$ & $\begin{array}{l}2.44 \mathrm{E}-5^{*} \\
(1.46 \mathrm{E}-5)\end{array}$ & $\begin{array}{l}-2.31 \mathrm{E}-5 \\
(1.75 \mathrm{E}-5)\end{array}$ \\
\hline Population Density & $\begin{array}{l}0.1395^{* * * *} \\
(0.1398)\end{array}$ & $\begin{array}{l}-0.2194 \\
(0.2444)\end{array}$ & $\begin{array}{l}0.1203^{* * * *} \\
(0.1608)\end{array}$ & $\begin{array}{l}-0.1663^{* * *} \\
(0.1573)\end{array}$ & $\begin{array}{l}-0.4921^{* * *} \\
(0.1888)\end{array}$ \\
\hline Percent Movers & $\begin{array}{l}0.0407^{* * *} \\
(0.0073)\end{array}$ & $\begin{array}{c}0.0108 \\
(0.0127)\end{array}$ & $\begin{array}{l}0.0283^{* * *} \\
(0.0083)\end{array}$ & $\begin{array}{l}0.0249^{* * *} \\
(0.0082)\end{array}$ & $\begin{array}{c}0.0405^{* * *} \\
(0.00979)\end{array}$ \\
\hline Bodily Injury Claims & $\begin{array}{c}0.2200 \\
(0.1498)\end{array}$ & $\begin{array}{l}-0.2195 \\
(0.2619)\end{array}$ & $\begin{array}{l}-0.1699 \\
(0.1723)\end{array}$ & $\begin{array}{l}-0.0668 \\
(0.1686)\end{array}$ & $\begin{array}{l}-0.0721 \\
(0.2023)\end{array}$ \\
\hline Rate Regulation & $\begin{array}{l}-0.0910^{*} \\
(0.0545)\end{array}$ & $\begin{array}{l}0.2772^{* * *} \\
(0.0952)\end{array}$ & $\begin{array}{l}-0.0114 \\
(0.0626)\end{array}$ & $\begin{array}{l}-0.0855 \\
(0.0613)\end{array}$ & $\begin{array}{l}-0.0148 \\
(0.0736)\end{array}$ \\
\hline Stringent Regulation & $\begin{array}{l}-0.3690^{* * * *} \\
(0.0772)\end{array}$ & $\begin{array}{l}-0.9053^{* * *} \\
(0.1349)\end{array}$ & $\begin{array}{l}-0.4823^{* * *} \\
(0.0888)\end{array}$ & $\begin{array}{l}-0.3581^{* * *} \\
(0.0869)\end{array}$ & $\begin{array}{l}-0.7787^{* * *} \\
(0.1043)\end{array}$ \\
\hline Adjusted R-sq & 0.6419 & 0.6104 & 0.5577 & 0.4427 & 0.6620 \\
\hline
\end{tabular}

Standard errors in parentheses. The model also includes year and ceasus division dummy variables not reported here.

*** significant at the .01 level.

** significant at the .05 level.

* significant at the .10 level. 
TABLE 7

1987 - 1992 Data by State

Consistently Regulated States

Ordinary Least Squares Estimation

Log - Odds Market Shares

\begin{tabular}{|c|c|c|c|c|c|}
\hline & $\begin{array}{l}\text { Direct } \\
\text { Writers }\end{array}$ & $\begin{array}{l}\text { National } \\
\text { Firms }\end{array}$ & $\begin{array}{l}\text { National } \\
\text { Direct } \\
\text { Writers }\end{array}$ & $\begin{array}{l}\text { National } \\
\text { Auto } \\
\text { Specialists }\end{array}$ & $\begin{array}{l}\text { Big } \\
\text { Four }\end{array}$ \\
\hline Intercept & $\begin{array}{l}-0.9156^{* * *} \\
(0.2540)\end{array}$ & $\begin{array}{l}-0.8983^{*} \\
(0.4570)\end{array}$ & $\begin{array}{l}-1.2688^{* * *} \\
(0.2905)\end{array}$ & $\begin{array}{l}-1.5280^{* * * *} \\
(0.2771)\end{array}$ & $\begin{array}{l}-1.2003^{* * *} \\
(0.3497)\end{array}$ \\
\hline Per Capita Income & $\begin{array}{l}3.12 \mathrm{E}-5 * * \\
(1.32 \mathrm{E}-5)\end{array}$ & $\begin{array}{l}1.32 \mathrm{E}-4^{* * *} \\
(2.37 \mathrm{E}-5)\end{array}$ & $\begin{array}{l}3.53 \mathrm{E}-5 * * \\
(1.51 \mathrm{E}-5)\end{array}$ & $\begin{array}{l}3.60 \mathrm{E}-5^{* *} \\
(1.44 \mathrm{E}-5)\end{array}$ & $\begin{array}{l}-5.23 \mathrm{E}-6 \\
(1.81 \mathrm{E}-5)\end{array}$ \\
\hline Population Density & $\begin{array}{c}0.0831 \\
(0.1411)\end{array}$ & $\begin{array}{l}-0.3206 \\
(0.2539)\end{array}$ & $\begin{array}{c}0.0621 \\
(0.1614)\end{array}$ & $\begin{array}{l}-0.1905 \\
(0.1540)\end{array}$ & $\begin{array}{l}-0.5991^{* * *} \\
(0.1943)\end{array}$ \\
\hline Percent Movers & $\begin{array}{l}0.0340^{* * *} \\
(0.0073)\end{array}$ & $\begin{array}{l}-0.0047 \\
(0.0132)\end{array}$ & $\begin{array}{c}0.0196 * * \\
(0.0084)\end{array}$ & $\begin{array}{l}0.0177^{* *} \\
(0.0080)\end{array}$ & $\begin{array}{l}0.0267^{* * *} \\
(0.0101)\end{array}$ \\
\hline Bodily Injury Claims & $\begin{array}{l}0.5023^{* * *} \\
(0.1683)\end{array}$ & $\begin{array}{c}0.1761 \\
(0.3028)\end{array}$ & $\begin{array}{c}0.1636 \\
(0.1925)\end{array}$ & $\begin{array}{c}0.3208 * \\
(0.1836)\end{array}$ & $\begin{array}{c}0.4141^{*} \\
(0.2317)\end{array}$ \\
\hline Competitive Freedom & $\begin{array}{l}0.0808^{* * *} \\
(0.0181)\end{array}$ & $\begin{array}{l}0.1432^{* * *} \\
(0.0326)\end{array}$ & $\begin{array}{l}0.1008^{* * *} \\
(0.0207)\end{array}$ & $\begin{array}{l}0.1066^{* * *} \\
(0.0198)\end{array}$ & $\begin{array}{l}0.1499^{* * *} \\
(0.0249)\end{array}$ \\
\hline Adjusted R-sq & 0.6292 & 0.5726 & 0.5468 & 0.4574 & 0.6363 \\
\hline
\end{tabular}

Standard ertors in parentheses. The model also includes year and census division dummy variables not reported here.

*** significant at the .01 level.

** significant at the .05 level.

* significant at the .10 level. 


\section{TABLE 8}

1987 - 1992 Data by State

Consistently Regulated States

Two Stage Least Squares Estimation

Log - Odds Market Shares

\begin{tabular}{|c|c|c|c|c|c|}
\hline & $\begin{array}{l}\text { Direct } \\
\text { Writers }\end{array}$ & $\begin{array}{l}\text { National } \\
\text { Firms }\end{array}$ & $\begin{array}{l}\text { National } \\
\text { Direct } \\
\text { Writers }\end{array}$ & $\begin{array}{l}\text { National } \\
\text { Auto } \\
\text { Specialists }\end{array}$ & $\begin{array}{l}\text { Big } \\
\text { Four }\end{array}$ \\
\hline Intercept & $\begin{array}{l}-1.4566^{* * * *} \\
(0.3489)\end{array}$ & $\begin{array}{l}-0.2538 \\
(0.6205)\end{array}$ & $\begin{array}{l}1.9305^{* * *} \\
(0.3975)\end{array}$ & $\begin{array}{l}-2.6401^{* * *} \\
(0.3939)\end{array}$ & $\begin{array}{l}-2.4762^{* * *} \\
(0.5194)\end{array}$ \\
\hline Per Capita Income & $\begin{array}{l}4.82 \mathrm{E}-5^{* * *} \\
(1.56 \mathrm{E}-5)\end{array}$ & $\begin{array}{l}1.04 \mathrm{E}-4^{* * *} \\
(2.77 \mathrm{E}-5)\end{array}$ & $\begin{array}{l}5.81 \mathrm{E}-5^{* * * *} \\
(1.77 \mathrm{E}-5)\end{array}$ & $\begin{array}{l}6.62 \mathrm{E}-5^{* * *} \\
(1.76 \mathrm{E}-5)\end{array}$ & $\begin{array}{c}4.18 \mathrm{E}-6 \\
(2.32 \mathrm{E}-5)\end{array}$ \\
\hline Population Density & $\begin{array}{c}0.1152 \\
(0.1456)\end{array}$ & $\begin{array}{l}-0.3357 \\
(0.2589)\end{array}$ & $\begin{array}{c}0.0945 \\
(0.1658)\end{array}$ & $\begin{array}{l}-0.1056 \\
(0.1643)\end{array}$ & $\begin{array}{l}-0.4163^{*} \\
(0.2167)\end{array}$ \\
\hline Percent Movers & $\begin{array}{l}0.0278^{* * *} \\
(0.0080)\end{array}$ & $\begin{array}{c}0.0054 \\
(0.0142)\end{array}$ & $\begin{array}{c}0.0112 \\
(0.0091)\end{array}$ & $\begin{array}{c}0.0065 \\
(0.0090)\end{array}$ & $\begin{array}{r}0.0226^{*} \\
(0.0119)\end{array}$ \\
\hline Bodily Injury Claims & $\begin{array}{l}0.7227^{* * *} \\
(0.1999)\end{array}$ & $\begin{array}{l}-0.0437 \\
(0.3556)\end{array}$ & $\begin{array}{r}0.4209^{*} \\
(0.2278)\end{array}$ & $\begin{array}{l}0.7993^{* * *} \\
(0.2257)\end{array}$ & $\begin{array}{l}1.1083^{* * *} \\
(0.2976)\end{array}$ \\
\hline Competitive Freedom & $\begin{array}{l}0.1339^{* * * *} \\
(0.0311)\end{array}$ & $\begin{array}{c}0.0903 \\
(0.0554)\end{array}$ & $\begin{array}{l}0.1627^{* * *} \\
(0.0355)\end{array}$ & $\begin{array}{l}0.2238^{* * * *} \\
(0.0352)\end{array}$ & $\begin{array}{l}0.3220^{* * * *} \\
(0.0464)\end{array}$ \\
\hline Adjusted R-sq & 0.6041 & 0.5352 & 0.5425 & 0.4443 & 0.5978 \\
\hline
\end{tabular}

Standard errors in pareatheses. The model also includes year and census division dummy variables not reported here.

*** significant at the .01 level.

** significant at the .05 level.

* significant at the .10 level. 


\section{TABLE A1}

1987-1992 Data by State

Summary Statistics for Regression Variables

\begin{tabular}{|c|c|c|c|}
\hline & Mean & Std. Dev. & $\mathrm{N}$ \\
\hline Number of Firms & 97.17 & 23.85 & 276 \\
\hline Number of Direct Writers & 26.92 & 6.65 & 276 \\
\hline Number of National Firms & 60.00 & 8.10 & 276 \\
\hline Number of National Direct Writers & 18.46 & 2.44 & 276 \\
\hline Number of National Auto Specialists & 16.17 & 2.39 & 276 \\
\hline Number of "Big Four" & 3.54 & 0.527 & 276 \\
\hline Direct Writers Market Share & 0.646 & 0.12 & 276 \\
\hline National Firms Market Share & 0.697 & 0.14 & 276 \\
\hline \multicolumn{4}{|l|}{ National Direct Writers } \\
\hline Market Share & 0.476 & 0.13 & 276 \\
\hline \multicolumn{4}{|l|}{ National Auto Specialists } \\
\hline Market Share & 0.432 & 0.11 & 276 \\
\hline “Big Four” Market Share & 0.422 & 0.14 & 276 \\
\hline Log (Registered Autos) & 14.27 & 0.97 & 276 \\
\hline Per Capita Income & 16999.77 & 3149.96 & 276 \\
\hline Population Density & 0.16 & 0.24 & 276 \\
\hline Territory Density & $8.2 E-6$ & $4.0 \mathrm{E}-6$ & 276 \\
\hline Percent Movers 1980-1990 & 11.22 & 4.69 & 276 \\
\hline \multicolumn{4}{|l|}{ Bodily Injury Claims/Ptoperty } \\
\hline Damage Claims & 0.40 & 0.16 & 276 \\
\hline Rate Regulation Dummy & 0.500 & 0.478 & 276 \\
\hline Stringent Regulation Dummy & 0.109 & 0.312 & 276 \\
\hline \multicolumn{4}{|l|}{ Conning Index of Competitive } \\
\hline Freedom & 5.29 & 1.63 & 276 \\
\hline
\end{tabular}

Source: A. M. Best Company Reports, 1989 